3. Hahn, D. Entwicklungstendenzen der strategischen Führung [Text] / D. Hahn // Technologie und Management. - 1992. Vol. 41, № 2. - P. 10-21.

4. Hahn, D. Planirovanie i kontrol': kontseptsiia kontrollinga [Text]: Translation from Germany / D. Hahn; ed. by A. A. Gurchak, L. G. Golovach, M. L. Lukashevich. - Moscow: Finance and statistics, 1997. - 800 p.

5. Horvath, P. Vahlens grosses Controllinglexikon [Text] / P. Horvath, T. Reichmann. - München: Beck, Vahlen, 1993. - 682 p.

6. Deyhle, A. Controller-Praxis. Führung durch Ziele, Planung und Controlling [Text] / A. Deyhle. - München: ControllerAkademie, Gauting, 2001. - 176 p.

7. Deyhle, A. Controller-Praxis [Text] / A. Deyhle, K. Eiselmayer, G. Kleinhietpass. - Freiburg: Verlag für ControllingWissen, 2016. - 350 p.

8. Reichmann, T. Controlling mit Kennzahlen [Text] / T. Reichmann. Muenchen: Vahlen, 2011. - 824 p. doi:10.15358/9783800643752

9. Brokhun, N. S. Bukhhalterskyi oblik yak instrument informatsiinoho zabezpechennia systemy kontrolinhu [Text]: PhD thesis: 08.00.09 / N. S. Brokhun. - Zhytomyr: Zhytomyr State Technological University, 2010. - $20 \mathrm{p}$.

10. Holov, S. F. Upravlinskyi oblik [Text]: Handbook / S. F. Holov. - Kyiv: Libra, 2003. - 704 p.

11. Pushkar, M. S. Kontrolinh - informatsiina pidsystema stratehichnoho menedzhmentu [Text]: Monograph / M. S. Pushkar, R. M. Pushkar. - Ternopil: Kart-blansh, 2004. - 370 p.

12. Suhareva, L. A. Kontroling - osnova upravleniia biznesom [Text] / L. A. Suhareva, S. N. Petrenko. - Kyiv: Elga, NikaTsentr, 2002. - 208 p.

13. Yakovliev, Yu. P. Kontrolinh na bazi informatsiinykh tekhnolohii [Text] / Yu. P. Yakovliev. - Kyiv: Tsentr navchalnoi literatury, 2006. - 318 p.

14. Shepitko, H. F. Kontrolinh [Text]: Handbook / H. F. Shepitko. Kyiv: European University, 2005. - 136 p.

15. Orehovskii, P. A. Kontrolling [Text]: Handbook / P. A. Orehovskii. - Obninsk: International Academy of Modern Knowledge, 2000. - 187 p.

16. Anankina, E. A. Kontrolling kak instrument upravleniia predpriiatiem [Text] / E. A. Anankina, S. V. Danilochkin, N. G. Danilochkina et al; ed. by N. G. Danilochkina. - Moscow: YuNITI, 2002. - 279 p.

17. Karminskii, A. M. Kontrolling v biznese. Metodologicheskie i prakticheskie osnovy postroeniia kontrollinga $\mathrm{v}$ organizatsiiah [Text] / A. M. Karminskii, N. I. Olenev, A. G. Primak, S. G. Falko.Ed. 2. - Moscow: Finance and statistics, 2002. - 256 p.
18. Karminskii, A. M. Kontrolling [Text]: Handbook / A. M. Karminskii, S. G. Falko, A. A. Zhevaga, N. Yu. Ivanova; ed. by A. M. Karminskii, S. G. Falko. - Moscow: Finance and statistics, 2006. - 336 p.

19. Popova, L. V. Kontroling [Text]: Handbook / L. V. Popova, R. E. Isakova, T. A. Golovina. - Moscow: Business and Service, 2003. - 192 p.

20. Portna, O. V. Kontrolinh [Text]: Handbook / O. V. Portna. Lviv: Mahnoliia 2006, 2008. - 240 p.

21. Folmut, H. I. Instrumenty kontrollinga ot A do Ya [Text]: Translation from Germany / H. I. Folmut; ed. by M. L. Lukashevich, E. N. Tihonenkova. - Moscow: Finance and statistics, 2003. - 288 p.

22. Horvat, P. Kontseptsiia kontrollinga: Upravlencheskii uchet Sistema otchetnosti. Biudzhetirovanie [Text] / P. Horvat et al. Moscow: Alpina Business Books, 2005. - 269 p.

23. Slutskin, M. L. Razrabotka sistemy kontrollinga na promyshlennom predpriiatii: teoreticheskie osnovy i metodologiia [Text] Dissertation Thesis of Doctor of Economic Sciences: 08.00.05 M. L. Slutskin. - Saint Petersburg, 2005. - 35 p.

\section{ОРГАНИЗАЦИЯ ОПЕРАТИВНОГО И СТРАТЕГИЧЕСКОГО} КОНТРОЛЛИНГА В УСЛОВИЯХ ИНТЕГРИРОВАННОЙ СИСТЕМЫ YЧETA

Даны определения оперативного и стратегического контроллинга, проанализированы существующие подходы к выделению объектов контроллинга, на основные чего идентифицированы объекты оперативного и стратегического контроллинга. Разработана система аналитических инструментов контроллинга с учетом особенностей их применения в контексте субсфер. Исследовано порядок функционирования систем стратегического и оперативного контроллинга в современных условиях хозяйствования.

Ключевые слова: объекты контроллинга, инструменты контроллинга, стратегический контроллинг, оперативный контроллинг.

Kutsyk Petro, PhD, Professor, Department of Accounting, Lviv University of Trade and Economics, Ukraine, e-mail: kucykpetro@mail.ru ORCID: http://orcid.org/0000-0001-8514-852X

Ostapyuk Natalia, Doctor of Economic Sciences, Professor, Department of Accounting and Taxation, Kyiv National Economics University named after Vadym Hetman, Ukraine, e-mail: ostapiuk@ukr.net, ORCID: http://orcid.org/0000-0003-2347-3815
Grinko A., Hrynko P.

\title{
RESEARCHES OF MODERN DEVELOPMENT OF BUSINESS ENVIRONMENT IN UKRAINE
}

Досліджено поняття «підприємнищьке середовище». Проаналізовано погляди вчених щодо його суті. Охарактеризовано зовнішні та внутрішні фактори, що впливають на ефективність розвитку підприємницького середовища та визначають його структуру. Проведено комплексну оцінку сучасного стану українського підприємницького середовища, яка дозволила визначити основні проблемні параметри та надати характеристику ділового та інвестиційного клімату в країні.

Ключові слова: підприємницьке середовище, управління бізнесом, інституційні механізми, прийняття рішень.

\section{Introduction}

The modern significance of the methodological substantiation of institutional mechanisms for ensuring the effectiveness of the development of the business environment is due to the growing role of entrepreneurship and the factors of activating its business activity in increasing the economic potential of the Ukrainian economy and in- 
creasing its competitiveness. Occupying a significant place in the national economy, entrepreneurship falls under the significant influence of political, social, cultural and other factors of social development. The effectiveness of the business environment is determined by the conditions of economic freedom and the development of organizational and economic innovation and how a complex integrated system is divided into external, as a rule, independent of entrepreneurs, and internal, which is formed directly by entrepreneurs. External business environment is determined by a combination of external factors and conditions, directly or indirectly affect its development. Political and social destabilization of society, the complications of doing business in certain areas of the country, the severance of economic ties not only with part of the neighboring countries, but also within the country, require the revision of various aspects of the organization and approaches to the impact on entrepreneurship and its development.

The problems of theoretical justification, the methodology of formation and effective management of the development of the business environment require the comprehension and clarification of directly original concepts of «entrepreneurship», «business environment», «institutional organization of entrepreneurship», «business infrastructure for business development».

\section{The object of research and its technological audit}

The object of research is a comprehensive system of regulation and management of modern entrepreneurship based on the modification of economic relations and creating conditions for the sustainable development of economic systems. The management of business relations in foreign practice is more effective, since productive business models are built with the settings of stable links between the blocks with the guiding influence, based on the initial parameters and the specified functional characteristics. Entrepreneurship effectiveness is a necessary measure for increasing the level of success of financial and economic relations, reaching a compromise between business entities and ensuring their sustainable competitive advantage. In accordance with the example of the best foreign practice, there is a system of servicing the primitive interests of entrepreneurship without excessive manipulation of the governing influence and consideration of key goals in the organization of partnerships that is realized through the efficiency of the functioning of economic systems. Of course, the example of foreign experience should be borrowed for domestic entrepreneurship with specific settings for organization of the Ukrainian economy, taking into account the factors, attributes and properties that characterize the current subjects of business relations. In accordance with this, development of measures, tools and mechanisms for organizing entrepreneurship management is expedient.

\section{The aim and objectives of research}

The conducted research is aimed at justifying the need to distinguish the business environment as an integral object of the national economy, influencing the creation of favorable conditions for the development of small and medium-sized businesses by increasing the effectiveness of state and regional support, attracting the population into production activities, eliminating administrative barriers that adversely affect the entrepreneurship institutionalization and stabilization of economic development of the state.

To achieve this aim, the following tasks are accomplished:

1. To investigate the genesis of the «business environment» and to make meaningful content of its definition.

2. To investigate the entrepreneurship development in Ukraine and dynamics of its indicators in the modern business conditions.

3. To outline the role of external and internal factors in the business environment.

\section{Research of existing solutions of the problem}

Significant number of scientific methodological works is devoted to the problem of development of the business environment. They are covered entrepreneurship issues, to which should be attributed the work of outstanding foreign economists. In particular, the essence and characteristic features of entrepreneurship are described [1], the institutional structure of modern economic relations is justified [2]. The theoretical and methodological foundations and essence of entrepreneurship, the purpose of organization and innovation of entrepreneurial culture are revealed [3]. The directions of introduction of foreign experience of venture investment mechanisms in the business sector of Ukraine are proposed [4]. The hierarchical system of factors for the organization and implementation of entrepreneurial activity is considered [5]. The effectiveness of state and market regulation of the national economy of Ukraine, institutional reforms, investment and innovation policy is estimated [6]. Theoretical and practical concepts on the formation and development of the private sector of the economy, entrepreneurship in the conditions of transformation of the Ukrainian economy are developed [7]. The regulatory and legal framework for regulating the organization of tax relations between business entities $[8]$ is determined. The necessity and the basic parameters (role, purpose, functions) of the economic management of the enterprise are argued [9]. The positive result of the harmonization of the domestic methodology for classifying business for the development of business activity, application of the world's leading scientific achievements in the field of entrepreneurship stimulation is underlined [10].

As noted by modern researchers, today there are no unified definitions of the above-mentioned concepts and, moreover, they are unlikely to be unambiguously interpreted, given the multi-purpose nature of their use, as well as differences in traditions, culture, politics and business development practices in different countries and regions. Despite the increased attention to entrepreneurship issues, a significant historical experience of research into its formation, social life brings new features that require further study of the formation of an effective business environment. In particular, it is necessary to take into account changes in state approaches to entrepreneurship, economic conditions, complicated by political and social instability, the implementation of business activities in certain areas of the country and the like. 


\section{Methods of research}

The theoretical basic research is the methodological and general scientific principles of conducting complex researches. The theoretical substantiation of the development of the business environment is carried out using a complex, purposeful system approach, analysis of indicators of graphic design.

\section{Research results}

The problem of understanding the essence of entrepreneurship was originally posed as a problem of justifying the sources of economic growth and the nature of profit.

The «entrepreneurship» concept was introduced as far back as the 18th century, which meant a specific kind of human activity that is realized in conditions of uncertainty and risk. The most typical and capacious, in our opinion, definition of entrepreneurship is provided by American scientists [1], characterizing entrepreneurship as the process of creating such new one that has value; a process that absorbs time and effort, involves assuming financial, moral and social responsibility; the process that brings exactly money income and personal satisfaction for what has been achieved. It was considered that components for entrepreneurship development are:

a) organizational and economic innovation;

b) economic freedom.

In another, more modern scientific approach (the new institutional economy), entrepreneur is viewed as a subject that makes a choice between the contractual relations of freedom of activity and factors, which are limited it. Entrepreneurship is a mechanism that regulates development of the socioeconomic sphere of society's life; Mechanism that supports the optimal balance between freedom and the need for social development, between chaos and order in the structural composition of society [2].

In Western countries, from a scientific and practical point of view, modern entrepreneurship is characterized as a special innovative, anti-bureaucratic form (style) of the economy, based on the search for new opportunities, orientation to innovation, the ability to attract and use resources from a wide variety of sources to solve assigned tasks.

Entrepreneurship is based on economic and social theories, according to which change is quite normal and natural phenomenon. New ideas form the content of the term «entrepreneurship», therefore the entrepreneurship task is «creative destruction».

That is, «persons who introduce new production functions that differ from reproduced old production functions and change the proportions and the number of factors of production within the latter are called entrepreneurs» [3].

Entrepreneurs are distinguished by an innovative type of thinking. And further - entrepreneurial is an enterprise not because it is new, and not because it is small, although it is developing rapidly, but because its activity is based on the realization that products that are manufactured have individual characteristics, the demand for which has grown to such extent that a «market niche» has been formed, and new technology makes it possible to turn complex operations into a scientific process.

The theoretical and practical importance of entrepreneurship is comprehensively elaborated on the impact on economy development. Particular attention is paid to the definition of a conceptual-categorical apparatus, characterizing the entrepreneurial economy, entrepreneurial society and entrepreneurial management. It is considered not only the problems of forming business environment, but also the motivation of entrepreneurs and the conditions for their business to be carried out [4].

If generalize the scientific definitions of business by Western scientists, we can determine that this is a matter of such behavior (processes) that show the initiative, organization and reorganization of the socio-economic mechanism in order to be able to use resources and a concrete situation and take responsibility for possible failure, i.e. readiness to take risks. In the definition, the economic, social, personal and managerial approaches are combined.

For entrepreneurship development in our country, it is important, in our opinion, to understand that not every new business is entrepreneurship (although, of course, it is possible to take any work in the formation of a market economy with certain reservations as entrepreneurship only with certain reservations). Entrepreneurship is primarily associated with the effective use of all factors of production for the purpose of economic growth and meeting the needs of individuals and society as a whole in goods (works, services) and obtaining the income necessary for the self-development of one's own business (enterprise) and ensuring financial obligations for the budget and other business entities, ultimately receiving material and moral rewards.

Entrepreneurship is inherently a type of management based on the innovative nature of the behavior of business owners, on the ability to find and use ideas, to implement them into concrete entrepreneurial projects. This is usually a risky business, and therefore should be carefully justified, based on knowledge of the sales market and competitors, while not neglecting your own intuition and, of course, the support of state bodies (especially when it comes to economically promising and socially significant projects).

An analysis of the views of Ukrainian economists proves that almost all scientists agree that the business environment is a certain condition that is created in society and influences the development and functioning of business.

Thus, entrepreneurship is defined as «a set of conditions and factors of the external order that affect the opportunities and outcomes of the activities of market entities, and also enable the entrepreneur to realize his goals and functions» [5]. Or as «socio-economic conditions and environmental factors that affect the functioning of the enterprise and require a response to it» [6]. It is noted that entrepreneurship is «a certain system that includes business entities, regulatory framework, political situation, social moods in society, how they affect the functioning of the enterprise and require an appropriate response to them» [7]. However, the most capacious is the characterization of entrepreneurship as manifestations of financial and economic relations in various spheres, the concept of which includes any work, purchase, commercial or industrial enterprise, commercial practice or the policy of an individual entrepreneur or an entire firm, based on compliance with the drawn up principles, the freedom of the entrepreneurial activities within the existing legal framework that the society has adopted to ensure maximum freedom of entrepreneurship [8]. 
Thus, the authors define entrepreneurship as «a set of conditions and factors of the external order that affect the possibilities and final results of the activities of market entities, and also allow the entrepreneur to realize his goals and functions» [5], in the author's opinion. Entrepreneurship is «socio-economic conditions and environmental factors that affect the operation of the enterprise and require a response to it», [6] and the other author that is «a certain system that includes business entities, the legal framework, the political situation, social moods in society, how they affect the functioning of the enterprise and require an appropriate response to them» [7].

The most complete definition, in our opinion, is given by the author [8] who believes that entrepreneurship manifests itself in various spheres of business, the concept of which includes any business, purchase, commercial or industrial enterprise, commercial practice or the policy of an individual entrepreneur or an entire firm on the basis of the principles, the freedom of business activity, within the existing legal framework, which the society has adopted to ensure maximum freedom of entrepreneurship.

So, entrepreneurship in a generalized sense reflects the totality of economic, social, organizational, personal and other relations that entrepreneur have with each other as economic agents, as well as consumers of their products (works, services), suppliers (raw materials, materials, equipment, fuel, electricity), with banks and other market entities, with hired workers (employees) and, finally, with the state in the person of relevant executive authorities and local self-government. The purpose of the entrepreneurship organization is making a profit and to be able to function for a long period of time.

That is, in our opinion, the business environment is an integrated set of various objective and subjective external and internal factors that mediate business relations and allow the entrepreneur to succeed in the implementation of certain goals, in the implementation of entrepreneurial projects and contracts with the receipt of profit (income) and implementation principle of a functioning enterprise.

We carried out a comprehensive assessment of the current state of the Ukrainian business environment, which allows to determine the main problem parameters of its current state, business and investment climate, and determine the position of Ukrainian business in the coordinates of international ratings of assessments of economic freedom and business competitiveness.

In particular, the following economic factors and conditions (indicators) affect positively (or negatively) the entrepreneurship development: development of entrepreneurship institution, inflation level; the number of taxes, fees and charges, and the amount of tax rates; liquidity level of economic partners (companies, firms), level of prices (tariffs) for certain types of resources, especially for products (services) of monopolies; preventing the establishment of monopolistically high or monopolistically low prices, as well as agreements of economic entities restricting competition in commodity markets. Important conditions are the continuous strengthening of the national monetary unit, increasing its purchasing power and some other factors and conditions. Undoubtedly, for the successful entrepreneurship development, the stability of the political situation in the country is needed, the recogni- tion by all branches of the government of the fact that without economic support, economic growth is impossible, improving the efficiency of the economy as a whole and the well-being of people.

To improve the efficiency of entrepreneurial activity, the development of the institutional and organizational environment has a noticeable impact. Many institutions (organizations) are entrepreneurial and, taking into account the specialization of their activities, render services and influence the corresponding entrepreneurial organizations. This applies to commercial banks, insurance organizations, wholesale and retail sellers, transport companies. Undoubtedly, significant role in entrepreneurship development belongs to state and regional funds for entrepreneurship supporting, the Chamber of Commerce and Industry, business associations (unions), as well as the mass media.

In recent years, Ukraine's position in international ratings has improved significantly, in particular, in the rating of favorable business conditions, which resulted from the adoption of separate reforms (Fig. 1).

Place

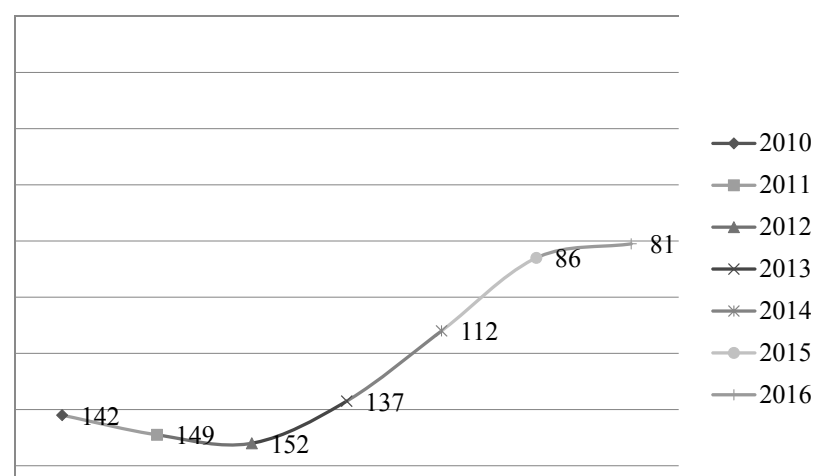

Fig. 1. The place of Ukraine in the World Bank's rating of business conditions

But the factors of the external environment cause sig nificant changes in the measures of state influence on the entrepreneurial sector, which quite often leads to its reduction and the reduction of entrepreneurship initiative and motivation.

As the conducted studies show, the dynamics of the number of registered subjects of entrepreneurial activity in Ukraine has decreased in recent years, which is connected with the instability of the economic situation against the background of the antiterrorist operation, the imperfection and inconsistency of the norms of the regulatory framework that requires constant monitoring of changes and adjustments in entrepreneurial activity, social moods in society at the macro level - the poverty of Ukrainian society that generates social tension, or the unfulfilled promises of the oligarchic leaders, etc. (Fig. 2).

Development of the business environment in Ukraine, unfortunately, can't fully operate under market conditions, which is explained, in most cases, by insufficient funds, lack of investment, and stringent credit conditions. Thus, according to statistical indicators, there is a significant reduction in the number of employees in 2015 compared to previous years by $3 \%$ (Fig. 3), despite the fact that sales volumes have increased (Fig. 3, 4). 


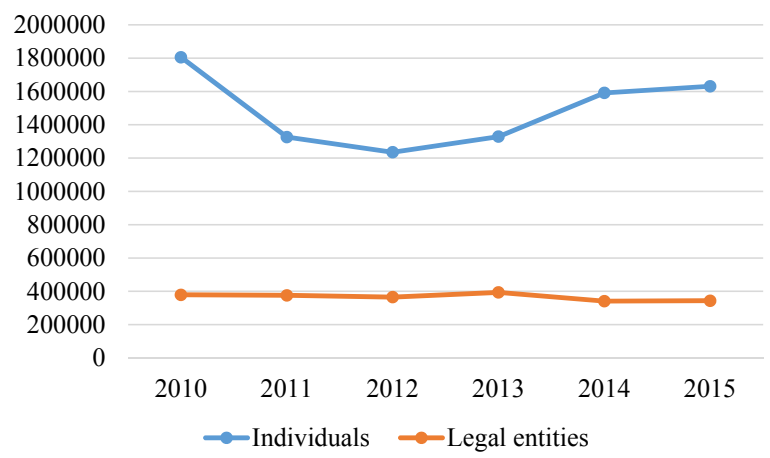

Fig. 2. Dynamics of the number of registered subjects of entrepreneurial activity in Ukraine

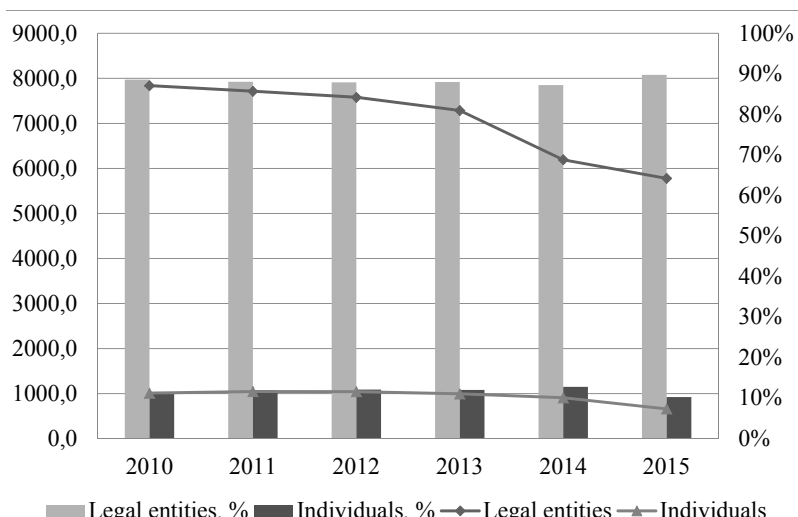

Fig. 3. Number of employees, thousand people

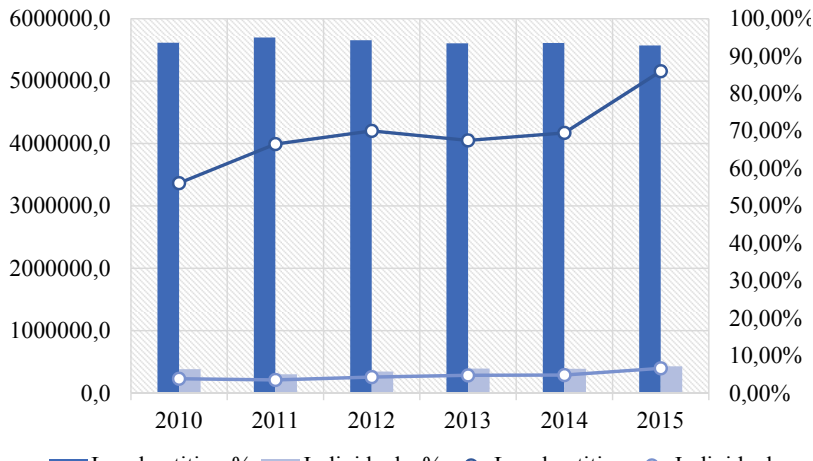

Legal entities, \% Individuals, \% - - - Legal entities -0 - Individuals

Fig. 4.The volume of sold products (goods, works, services), million UAH

The adoption in 2017 of changes to the Tax Code of Ukraine [9] on the payment of taxes by entrepreneurs, starting from 01/01/2017 in connection with the abolition of a special regime for VAT taxation of all agricultural producers, with the introduction of new rules for applying a zero interest rate for payers of income tax, an increase in the minimum wage fees that affects pricing, paying taxes registered but temporarily not working entrepreneurs, increasing penalties will lead to a reduction in the number of entrepreneurs, and accordingly, and decrease in the number of hired and employed workers, sales volumes and the like.

The modern realities of Ukrainian public life demonstrate the high dependence of entrepreneurship in Ukraine on external conditions. Also, the country's course towards European integration significantly influences the changes in the conditions for carrying out business activities, which requires the state to combine European experience in regu- lating entrepreneurship with measures conducive to the development of the entrepreneurial sector in conditions of instability and a reduction in the entrepreneurial initiative.

The internal business environment is also determined by the set of internal conditions and factors of the functioning of the entrepreneurial organization. These include: the availability of the necessary amount of equity capital; correct (justified) choice of the organizational and legal form of the enterprise (organization) and the subject of the activity; selection of team of partners; market knowledge and qualified marketing research; recruitment and management of personnel, its financial incentives; a mechanism for preserving trade secrets and the like.

In addition, the trends in the market economy dictate the need for effective management of the enterprise, which allows it to function at the expense of competitive advantages. The basis for ensuring the stable functioning of enterprises is the growth of their profitability, competitiveness, solvency and market value as key parameters of the enterprise's ability to develop, which directly depend on the mutually agreed activity of all its divisions. The effectiveness of their interaction is ensured through a specially organized system - the economic management of the enterprise

The restoration of the economic system, the creation of an innovative environment are ensured, which causes the acceleration of the economy's movement in the direction of efficiency, rationalization, thrift and constant renewal [11].

Thus, the conclusions on the need to distinguish the business environment as an integrated set of objective and subjective external and internal factors and conditions that mediate business relations and determine the mode of functioning of entrepreneurial organizations are justified, thus making it possible to study the institutional organization of the business development environment as an object. The state and dynamics of the business environment development have been studied, which requires the improvement of state policy by: improving legal, economic and organizational conditions as an important factor in the development and structural reorganization of the national economy, and the targeted formation of a system of state and public support.

\section{SWOT analysis of research results}

Strengths. Implementation of entrepreneurship management is designed to ensure the stable functioning of the economy, the growing competitiveness of economic systems in the global market environment. Leading influence on the business environment allows to optimize business processes and increase the sensitivity of indicators of entrepreneurship development to changes in the external economic environment. The proposals on the entrepreneurship management have been made allow to optimize economic relations and links with the modification of planning for the further development of the entrepreneurial sector.

Weaknesses. A restriction in the implementation of conclusions and proposals is the necessity to rebuild modern models of economic ties. This is the necessity to implement new basic regulators of entrepreneurship management and to harmonize them with traditional principles and factors.

Opportunities. In the future it is planned to define a new vector of development of entrepreneurship management 
concept with the provision of new methods for organizing business processes. It is planned to expand the parametrization in the management of entrepreneurial structures, which will help optimize financial and economic relations. One of the planned tasks is development of proposals for entrepreneurship management based on the conceptual basis of the behavioral theory of economic development.

Threats. The proposed changes require changes and transformations in the macro environment with a proper institutional foundation, which is complicated by a certain disintegration of factors and tools for producing managerial influence in entrepreneurship.

\section{Conclusions}

1. The content of the notion of «business entrepreneurial environment» is further developed through research and analysis of existing approaches of foreign and domestic economists.

2. The tendencies of the development of the business environment in Ukraine is analyzed, which allowed defining the main problem issues and directions for their solution, indicators of the current state of entrepreneurship, investment climate, the position of Ukrainian business in the coordinates of international ratings of economic freedom assessments and business competitiveness.

3. The influence of internal and external factors on development of the domestic business environment is investigated. These factors demonstrate the high dependence of entrepreneurship on them in Ukraine. External factor should be considered the development of the institutional and organizational environment, and internal factors include a set of internal conditions for the functioning of entrepreneurial structures.

\section{Rerences}

1. Hizrich, R. Predprinimatel'stvo ili kak zavesti sobstvennoe delo i dobit'sia uspeha [Text] / R. Hizrich, M. Piters. - Moscow: Progress-Unevers, 1991. - 160 p.

2. Coase, R. H. The Firm, the Market, and the Law [Text] R. H. Coase. - University of Chicago Press, 1987. - 217 p. doi:10.7208/chicago/9780226051208.001.0001

3. Schumpeter, J. A. BUSINESS CYCLES. A Theoritical, Historical and Statistical Analysis of the Capitalist Process [Text] / J. A. Schumpeter. - New York, Toronto, London: McGrawHill Book Company, 1939. - 461 p. doi:10.1522/030021081
4. Asaul, A. N. Metodologicheskie aspekty formirovaniia i razvitiia predprinimatel'skih setei [Text] / A. N. Asaul, E. G. Skumatov, G. E. Lokteva. - St. Petersburg: Gumanistika, 2004. - 256 p.

5. Butenko, A. I. Pidpryiemnytstvo v Ukraini: napriamky rozvytku [Text] / A. I. Butenko, I. M. Saraieva, S. V. Yakymov. - Odesa: Feniks, 2007. - 68 p.

6. Kredisov, V. A. Systema suspilno-ekonomichnykh chynnykiv funktsionuvannia pidpryiemnytstva [Text] / V. A. Kredisov // Formuvannia rynkovykh vidnosyn v Ukraini. - 2004. № 3 (34). - P. 3-9.

7. Mantsurov, I. H. Statystyka ekonomichnoho zrostannia ta konkurentospromozhnosti krainy [Text]: Monograph / I. H. Mantsurov. - Kyiv: Kyiv National Economics University named after Vadym Hetman, 2006. - 392 p.

8. Madzihon, V. V. Problemy optymizatsiinoho rozvytku pidpryiemnytstva v Ukraini na suchasnomu etapi [Text] / V. V. Madzihon // Molod i rynok. - 2011. - № 7 (78). P. 23-27.

9. Podatkovyi kodeks Ukrainy [Electronic resource]: Law of Ukraine from 02.12.2010 № 2755-VI. - Available at: \www/ URL: http://zakon2.rada.gov.ua/laws/show/2755-17

10. Ligonenko, L. A. Substantiation of Economic Management of a Company from the Point of View of the Theory of the Firm [Text] / L. A. Ligonenko // Business Inform. - 2013. № 5. - P. 227-231.

11. Kotliarevsky, O. Development of the system of entrepreneurship in Ukraine [Text] / O. Kotliarevsky // Ekonomika ta derzhava. - 2014. - № 12. - P. 128-132.

\section{ИССЛЕДОВАНИЯ СОВРЕМЕННОГО РАЗВИТИЯ} ЛРЕДПРИНИМАТЕЛЬСКОЙ СРЕДЫ В УКРАИНЕ

Исследовано понятие «предпринимательская среда». Проанализированы взгляды ученых его сущности. Охарактеризованы внешние и внутренние факторы, влияющие на эффективность развития предпринимательской среды и определяющие его структуру. Проведена комплексная оценка современного состояния украинской предпринимательской среды, которая позволила определить основные проблемные параметры и дать характеристику делового и инвестиционного климата.

Ключевые слова: предпринимательская среда, управление бизнесом, институциональные механизмы, принятие решений.

Grinko Alla, Doctor of Economic Sciences, Professor, Department of Accounting, Audit and Taxation, Kharkiv State University of Food Technology and Trade, Ukraine, e-mail: grinko.alla@gmail.com, ORCID: http://orcid.org/0000-0001-5324-6926

Pavlo Hrynko, PhD, Associate Professor, Department of International Economics, Kharkiv State University of Food Technology and Trade, Ukraine, e-mail: pavel.grunko@gmail.com, ORCID: http:// orcid.org/0000-0002-7011-6653 